\title{
Effects of safety barrier life cycle cost factors - identification and analysis
}

\author{
Adam Kristowski ${ }^{1}$, Beata Grzyl $^{1}$, Anna Gobis ${ }^{2, *}$, and Lukasz Jeliński ${ }^{2}$ \\ ${ }^{1}$ Gdansk University of Technology, Faculty Of Civil and Environmental Engineering, Highway and \\ Transportation Engineering Department, 11/12 Narutowicza Str., 80-233 Gdansk, Poland \\ ${ }^{2}$ Gdansk University of Technology, Faculty Of Civil and Environmental Engineering, Metal \\ Structures and Construction Management Department, 11/12 Narutowicza Str., 80-233 Gdansk, \\ Poland
}

\begin{abstract}
The costs borne by road infrastructure authorities for managing and maintaining road devices such as safety barriers may be very high. This has prompted the need for identifying and analysing in detail all factors that influence the costs of safety barriers throughout their service life. To meet that need, the authors used international experience and field data collected under the LifeRoSE project to define the cost structure and, as a next step, to analyse factors that are relevant to the costs actually incurred.
\end{abstract}

\section{Introduction}

When designers and investors decide on a specific type of safety barrier, they will usually consider the technical and economic aspects (the initial costs to buy). In practice, however, this leaves road infrastructure authorities with a major problem of having to pay high costs of safety barrier maintenance and operation (this includes maintenance and repairs) [1]. A basic tool for road infrastructure management [2] is to calculate the life cycle costs (LCC) of a road device which looks at the expenditure incurred at each stage of safety barrier life cycle: planning, design, construction, operation and decommissioning. When developing a method for life cycle cost assessment it is important to define the structure of costs to be borne throughout the entire life cycle. The objective of the authors' work under the LifeRoSE project is to identify and determine factors that are the main cost drivers in safety barrier life cycle. It is assumed that once collected and classified, the safety barrier cost data will form a basis for building a method for safety barrier life cycle cost assessment.

\section{International experience}

The LCC analysis is increasingly often used as a decision support tool to help with assessing and selecting alternative products [3]. The general principles and conditions for conducting LCC analyses are covered in a country's standards. As an example, Poland's PN-EN 60300 standard distinguishes six main product life cycle phases: concept and definition, design and

\footnotetext{
* Corresponding author: anngobis@.pg.edu.pl
} 
development, manufacture, installation, use and operation, decommissioning. These phases include an analysis and identification of factors influencing the product's life cycle costs. The analysis should begin with establishing the overall structure of cost components to be broken down into the smallest possible details, i.e. cost elements. These should then be presented using mathematical formulas, constant value functions and cost parameters (e.g. cost per working hour of repairs and regular maintenance) [4].

In a broad sense the literature [5-7] gives a varied representation of life cycle phases which are part of cost assessment. Costs are assessed for the entire life cycle of a product/structure, a single phase or a combination of different phases.

A simple way to break down the costs of safety barriers costs was applied in the United States. A research team compiled and assessed the costs of cable and concrete median barriers in 27 regions of Texas. The study helped to distinguish two main categories of costs without further detail: non-recurring (installation) and recurring. The factors that influence barrier LCC include: barrier material, frequency of crashes and the related traffic, barrier location and road condition, average time to repair and the costs of labour, equipment and materials used for barrier repairs. While the frequency of cable barrier hits depends on a number of factors, average daily traffic (ADT) and barrier location (distance from road) are particularly important. The frequency of cable barrier hits also depends on road surface conditions. Earlier ISPE analyses have shown that crashes tend to happen more often when the road is wet. Weatherford maintenance data seem to confirm this with more than half of barrier hits, i.e. $55 \%$ of the cases, occurring when the roadway is wet or slick. Ohio's share is at about $60 \%[8]$.

A more extended approach was applied in the United Kingdom. The analysis covered the M25 Sphere, a network of motorways surrounding London. The study looked at metal and concrete median barriers. The costs were split into two main groups: the costs to build and use, further divided into initial costs related to traffic and maintenance when an accident happens. In assessing the costs of barrier life cycle the following factors were included: barrier material, length and number of damaged elements, delays as a result of traffic disruptions, accidents involving barriers and accident severity and the costs of inspection and maintenance [9].

Sweden analysed repair data for more than 1600 barriers in four regions. To identify the cost factors and their number, designers, contractors, road authorities, technical specifications and project valuations were consulted. Factor analysis was conducted for median barriers, i.e. steel, cable and concrete barriers. This led to the identification of life cycle cost components, i.e. investment, maintenance and socio-economic aspects. Having established the structure of the costs, the next step was to identify factors that have the strongest bearing on total barrier life cycle costs. The work helped to distinguish parameters that determine the life cycle costs of specific types of safety barriers. They are: average annual traffic, costs to install and buy barriers, number of fatality accidents and light injury accidents, unit costs of accident victims, speed limits, time to repair a single damage, length of sections with lower speed limits, time to clean barrier reflective elements, road type, speed limit and seasonality [10].

Part of the research was designed to identify the importance of road type, speed limit, barrier type and region (north, east, west or south) for the costs to maintain median barriers [11]. The study looked at three types of roads: motorways, dual carriageways and $2+1$ roads. The results show that median barrier hits are most frequent on $2+1$ cross-sections with cable barriers, followed by motorways with steel barriers. The size of the damage and barrier repair costs are higher for cable barriers as opposed to steel barriers. This is because the structure of cable barriers is not strong enough. Winter conditions are also a contributing factor with winter barrier maintenance costs higher than those in the summer. The effects of speed limits on barrier damage costs are difficult to define reliably. Based on the results of the studies and 
analyses it was found that there a number of factors that determine safety barrier life cycle costs.

\section{Identification and analysis of cost factors}

\subsection{Cost components}

A study of the literature and the authors' initial research [12] helped to identify a division of safety barrier life cycle costs including a three-tier level of detail (Fig. 1). Based on this division, safety barrier life cycle costs are the sum of fixed and variable costs.

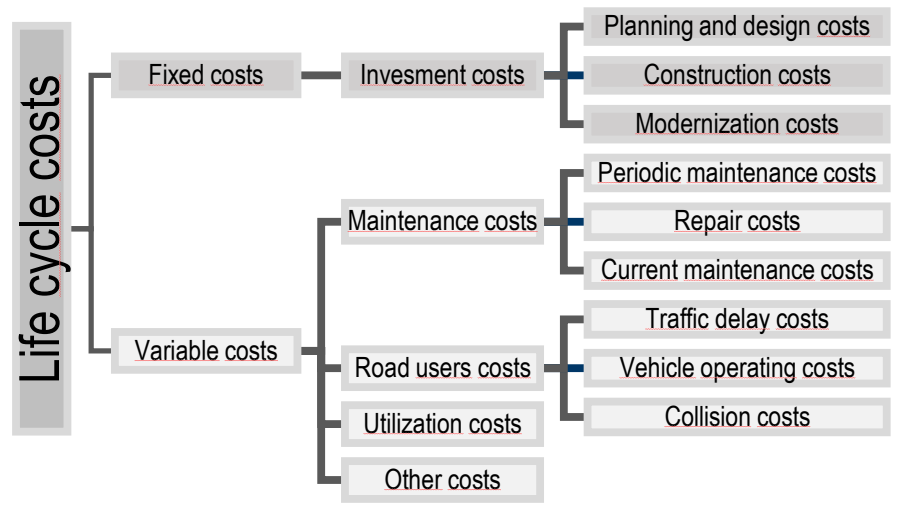

Fig. 1. Components of safety barrier life cycle costs. Authors' work.

Fixed costs are investment costs incurred primarily during the first cycle of a structure's service life and include: planning and design costs, construction costs and modernisation costs of safety barriers.

Variable costs are costs that change throughout the life cycle depending on the period. They comprise maintenance costs (day-to-day and periodical maintenance, costs to repair damage), user costs (road user delay costs, costs of vehicle operation and accident costs), costs to dismantle safety barriers and other costs not included in the groups of costs.

Based on the above, the key factors were identified and analysed for their effect on life cycle costs in Polish conditions. The analyses had the following basis:

- data collected in the LifeRoSE project on safety barrier accidents on sections of national roads featuring a variety of road and traffic conditions and a varying degree of road safety equipment provision [12],

- cost information from barrier manufacturers and maintenance companies,

- bulletins of roadworks prices,

- data from the general traffic count on national roads (GPR2015),

- data from SEWIK, a police road accident database, and SEZAR, a national road accident database,

- a test site with sections of different class national roads, $2845 \mathrm{~km}$ long.

The factor analysis was carried out in four cost categories:

- investment costs,

- maintenance costs,

- road user costs,

- removal costs. 


\subsection{Investment costs}

Investment costs are the sum of expenditures incurred to buy and modernise safety barriers. The costs of purchase occur during the manufacture, installation and acceptance of a structure.

Planning and design costs: research and implementation, development of technical design. These costs are estimated based on the expected cost of construction and do not exceed $3.5 \%$ of the anticipated costs of construction.

Construction costs - cost to manufacture, deliver and install barriers. To analyse the factors relevant to this group of costs, the information was sourced from roadworks price bulletins and manufacturers and maintenance companies. The analyses showed that time is not a major factor for unit costs of construction. Over the last 10 years no significant changes have been recorded in the costs listed in roadworks price bulletins with the differences between extreme prices (maximal and minimal) and the average not exceeding 5\%. Unit costs of construction, however, differ from bulletin to bulletin depending on the barrier material (steel, cable, concrete), weight (pole spacing) in the case of steel barriers and type of construction (one-sided, double-sided) in the case of steel barriers.

The next source of construction cost information was barrier manufacturers and maintenance companies. The cumulative data are given in Table 1 and in Fig. 2.

As we can see from the data, the cost to build a bridge barrier is double that of road barriers. Considering the construction material, cable barriers are the cheapest, with steel barriers double the price and concrete barriers nearly four times more expensive. The decisions to select a specific safety barrier are mostly based on these costs.

The costs of steel barriers vary significantly because they offer different levels of containment (Fig. 2). The construction costs of barriers were analysed for their level of containment. As we can see from the analysis, the higher the level of containment, the higher the barrier cost. This results from the weight of steel used to manufacture the different types of safety barriers. In addition, it was found that average construction costs are inversely proportional to barrier working width.

Table. 1. Costs of road and bridge barriers provided by manufacturers.

\begin{tabular}{|c|c|c|c|c|c|c|}
\hline $\begin{array}{c}\text { Barrier } \\
\text { material }\end{array}$ & $\begin{array}{c}\text { Barrier } \\
\text { type }\end{array}$ & $\begin{array}{c}\text { Number } \\
\text { of data } \\
\mathrm{N} \\
{[-]}\end{array}$ & $\begin{array}{c}\text { Mean cost } \\
\mathrm{C}_{\text {mean }} \\
{[\mathrm{PLN} / \mathrm{m}]}\end{array}$ & $\begin{array}{c}\text { Minimal } \\
\text { cost } \\
\mathrm{C}_{\min } \\
{[\mathrm{PLN} / \mathrm{m}]}\end{array}$ & $\begin{array}{c}\text { Maximal } \\
\text { cost } \\
\mathrm{C}_{\max } \\
{[\mathrm{PLN} / \mathrm{m}]}\end{array}$ & $\begin{array}{c}\text { Cost standard } \\
\text { deviation } \\
\text { SD } \\
{[\mathrm{PLN} / \mathrm{m}]}\end{array}$ \\
\hline steel & road & 64 & 189.03 & 85.28 & 801.30 & 109.98 \\
\hline steel & bridge & 22 & 509.61 & 221.40 & 1340.00 & 286.48 \\
\hline cable & road & 12 & 104.52 & 83.64 & 142.68 & 18.78 \\
\hline cable & bridge & 2 & 276.75 & 276.75 & 276.75 & 0.00 \\
\hline concrete & road & 1 & 492.00 & 492.00 & 492.00 & - \\
\hline
\end{tabular}

A comparative analysis of the costs from barrier manufacturers and maintenance companies and the prices listed in roadworks bulletins shows that the unit safety barrier purchase price is determined by the same factors. 


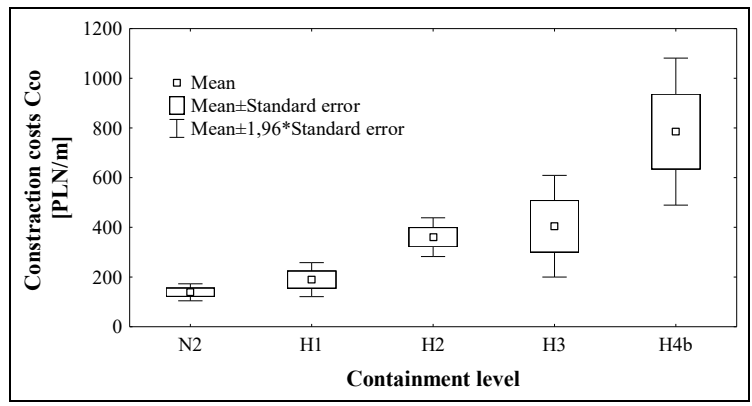

Fig. 2. Comparison of steel barrier construction costs by containment level.

Modernisation costs - because modernisation cost data are not available, it was assumed that the value and its effect on barrier total life cycle cost is the same as for the barrier construction cost.

\subsection{Maintenance costs}

Roads are maintained by road authorities directly or maintenance is contracted out to maintenance companies to ensure that road users stay safe as much as possible when vehicles leave the road. Keeping safety barriers functional and useable requires a number of actions and treatments. These produce maintenance costs in the course of periodical and day-to-day maintenance and during barrier repairs $[13,14]$.

Costs of periodical and day-to-day maintenance include expenditures on cleaning, renewal of barrier anti-corrosion coatings, exchange of corroded barrier joints and inspection rounds. Because periodical and day-to-day maintenance data are not available, an analysis of the parameters influencing these costs was not conducted.

Costs of barrier repairs - these include costs connected to barrier crashes, barrier damage and the need to repair barriers as a result. Using historical data from 2016 (Fig. 3) from sections of S6 and S7 national roads, a relation was presented between the number and costs of vehicle barrier impacts and the effects of seasonality on barrier accidents and the total cost of that. The results show that there is a fairly close relation between the number of barrier vehicle hits and the costs of barrier damage in the particular months (correlation coefficient $\mathrm{R} 2=0.89-0.92$ ). As regards the $\mathrm{S} 6$ road, most accidents were recorded in December with the highest costs incurred in October. In the case of the S7 road, the highest costs and most accidents occurred in June. Because the results varied substantially, seasonality was not found to be a factor influencing total repair costs.

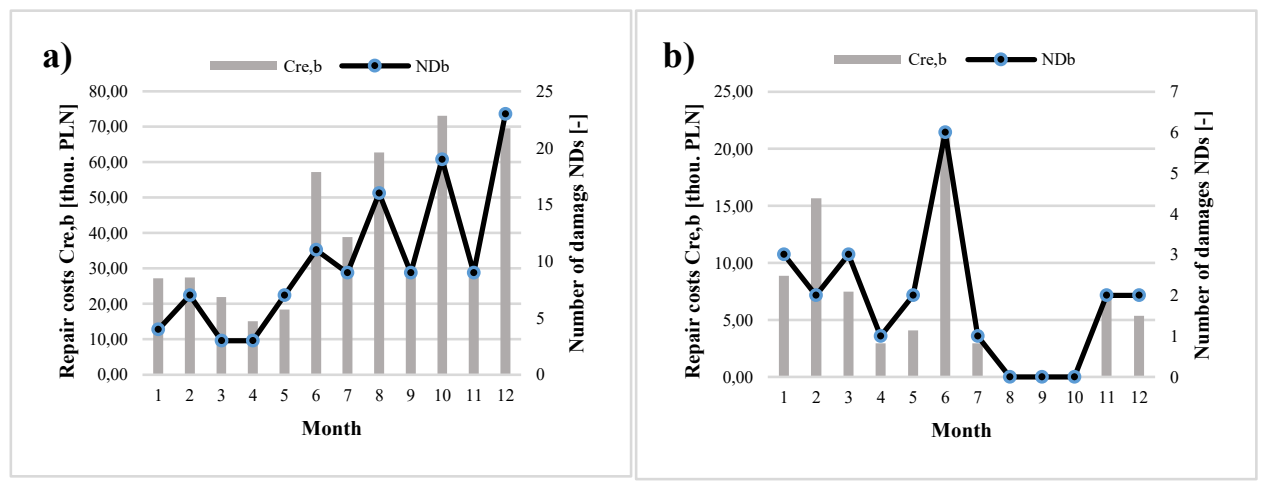

Fig. 3. Distribution of damage $\mathrm{ND}_{\mathrm{b}}$ and costs of barrier repairs over the months $\mathrm{Cre}_{\mathrm{b}}$ on selected sections of: a) S6, b) S7. 
Costs of safety barrier repairs depend on the type of barrier and length of damage after the barrier has been hit by a vehicle. The costs of safety barrier damage are largely influenced by road class as can be seen from the barrier repair cost data covering one year and representing the selected test road sections (Fig. 4). The higher the road class, the higher the average repair costs. As we know from the literature [15], [16], [17] the length of safety barrier damage after it has been hit by a vehicle depends on barrier location, vehicle weight, vehicle speed and angle of vehicle impact into barrier. Considering this (high vehicle speeds and high share of heavy goods vehicles), it is likely that higher class roads (motorways and express roads) will involve high costs of barrier repairs.

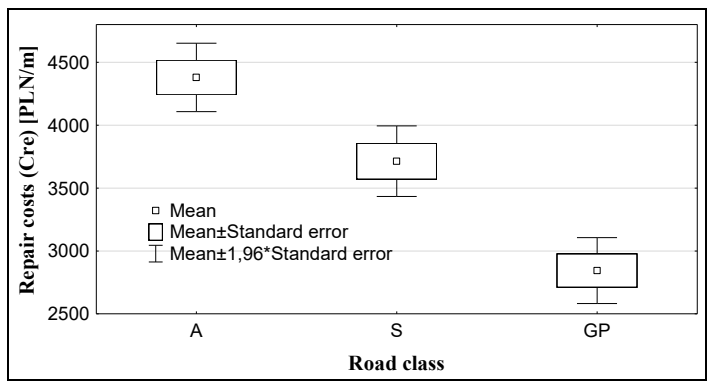

Fig. 4. Comparison of safety barrier repair costs in relation to road class.

\subsection{Road user costs}

Road user costs are defined as the consequences suffered by individuals or the public as a whole when a vehicle crashes into a safety barrier. The consequences include costs of road accidents, vehicle operating costs and costs of road user delay.

Costs of road accidents have to do with the negative impact a barrier has as an obstacle located in the roadside safety zone. Run-off-road accidents, including vehicles hitting a roadside tree, utility pole, sign or safety barrier represent about $10 \%$ of all of Poland's accidents which kill more than $18 \%$ of road users generating even higher costs. Road accident costs were estimated as the sum of the product of unit accident costs and their number where unit accident costs include operational and material consequences but also consequences suffered as a result of injury and death. The consequences of injury are represented as slight injury, medium injury and serious injury. The number of road accidents and accident severity are determined by the following factors: traffic volume, road class, share of HGVs in traffic, vehicle speed and barrier type. On the test site selected for the analysis in the years 20122016 (Table 2) there were more than 467 accidents involving vehicles hitting a safety barrier which represents about $12 \%$ of all accidents on the road sections under analysis (Table 3 ).

Tab. 2. Cumulative list of road accidents involving safety barriers on the test site (road sections) between 2012 and 2016 by road class.

\begin{tabular}{|l|c|c|c|c|c|c|}
\hline \multicolumn{1}{|c|}{ Road class } & $\begin{array}{c}\text { Length of } \\
\text { test section } \\
\text { Ls } \\
{[\mathrm{km}]}\end{array}$ & $\begin{array}{c}\text { Total } \\
\text { accidents } \\
\text { NAs } \\
\text { [acc./5 yrs.] }\end{array}$ & $\begin{array}{c}\text { Total barrier } \\
\text { accidents } \\
\text { NAb } \\
\text { [acc./5 yrs.] }\end{array}$ & $\begin{array}{c}\text { Injuries } \\
\text { RIb } \\
\text { [casualties/ } \\
5 \text { yrs.] }\end{array}$ & $\begin{array}{c}\text { Fatalities } \\
\text { RFb } \\
\text { [fatalities/ } \\
5 \text { yrs.] }\end{array}$ & $\begin{array}{c}\text { Barrier } \\
\text { accident costs } \\
\text { ACb [PLN } \\
\text { m/ 5 yrs.] }\end{array}$ \\
\hline Motorways (A) & 1201.0 & 1237 & 233 & 319 & 25 & 202.9 \\
\hline Express roads (S) & 1057.6 & 1019 & 167 & 211 & 20 & 140.8 \\
\hline Fast traffic trunk roads (GP) & 449.0 & 1422 & 63 & 71 & 6 & 41.0 \\
\hline Trunk roads (G) & 137.3 & 200 & 4 & 4 & 0 & 0.3 \\
\hline \multicolumn{1}{|c|}{ Sum } & $\mathbf{2 8 4 4 . 9}$ & $\mathbf{3 8 7 8}$ & $\mathbf{4 6 7}$ & $\mathbf{6 0 5}$ & $\mathbf{5 1}$ & $\mathbf{3 8 5 . 0}$ \\
\hline
\end{tabular}


Tab. 3. Comparison of accidents involving safety barriers by road class on the test site (road sections) between 2012 and 2016.

\begin{tabular}{|l|c|c|c|c|c|}
\hline Road class & $\begin{array}{c}\text { Length of } \\
\text { test section } \\
\text { Ls } \\
{[\mathrm{km}]}\end{array}$ & $\begin{array}{c}\text { Share of } \\
\text { barrier } \\
\text { accidents } \\
\text { PAb } \\
{[\%]}\end{array}$ & $\begin{array}{c}\text { Density of } \\
\text { barrier } \\
\text { accidents } \\
\text { DAb } \\
\text { [acc./km/5 } \\
\text { yrs.] }\end{array}$ & $\begin{array}{c}\text { Density of } \\
\text { accident barrier } \\
\text { costs } \\
\text { DACb } \\
{[\text { PLN m/km/5 }} \\
\text { yrs.] }\end{array}$ & $\begin{array}{c}\text { Average cost } \\
\text { of barrier } \\
\text { accidents } \\
\text { AACb } \\
\text { [PLN m/acc. }]\end{array}$ \\
\hline Motorways (A) & 1201.0 & 18.8 & 0.194 & 0.169 & 0.871 \\
\hline Express roads (S) & 1057.6 & 16.4 & 0.158 & 0.133 & 0.843 \\
\hline Fast traffic trunk roads (GP) & 449.0 & 4.4 & 0.140 & 0.091 & 0.651 \\
\hline Trunk roads (G) & 137.3 & 2.0 & 0.029 & 0.002 & 0.075 \\
\hline \multicolumn{1}{|c|}{ Sum/ average } & $\mathbf{2 8 4 4 . 9}$ & $\mathbf{1 0 . 4}$ & $\mathbf{0 . 1 3 0}$ & $\mathbf{0 . 0 9 9}$ & $\mathbf{0 . 6 1 0}$ \\
\hline
\end{tabular}

The analyses suggest that the higher the road class:

- the higher the share of barrier hits in overall accidents (from $2 \%$ on trunk roads $(G)$ to $18.8 \%$ on motorways $(\mathrm{A})$ ),

- the higher the costs of safety barrier hits (from PLN $0.07 \mathrm{~m}$ on trunk roads (G) to PLN $0.88 \mathrm{~m}$ on motorways (A)),

- the higher the density of barrier accident costs (from 0.002 on trunk roads (G) to PLN $0.167 \mathrm{~m} / \mathrm{km} / 5$ years on motorways (A)),

The reason for the differences is that higher class roads have more safety barriers, feature more traffic and higher speeds as is typical for motorways and express roads unlike other roads.

Running costs of vehicles - they are additional costs of fuel consumption and vehicle wear and tear as a result of longer travel times due to vehicles hitting safety barriers and barrier repairs.

Costs of delays - these are costs of delays to road users in connection with hitting a barrier. In both cases it is mean delays that matter most, i.e. the time from the accident until normal traffic is resumed. Figure 5 shows the distribution of traffic disruption times as a result of an accident on a selected section of the S12 national road in 2017. The delays will differ depending on the type and severity of the accident, number of vehicles involved in an accident, number of traffic lanes blocked and traffic volume $[18,19]$.

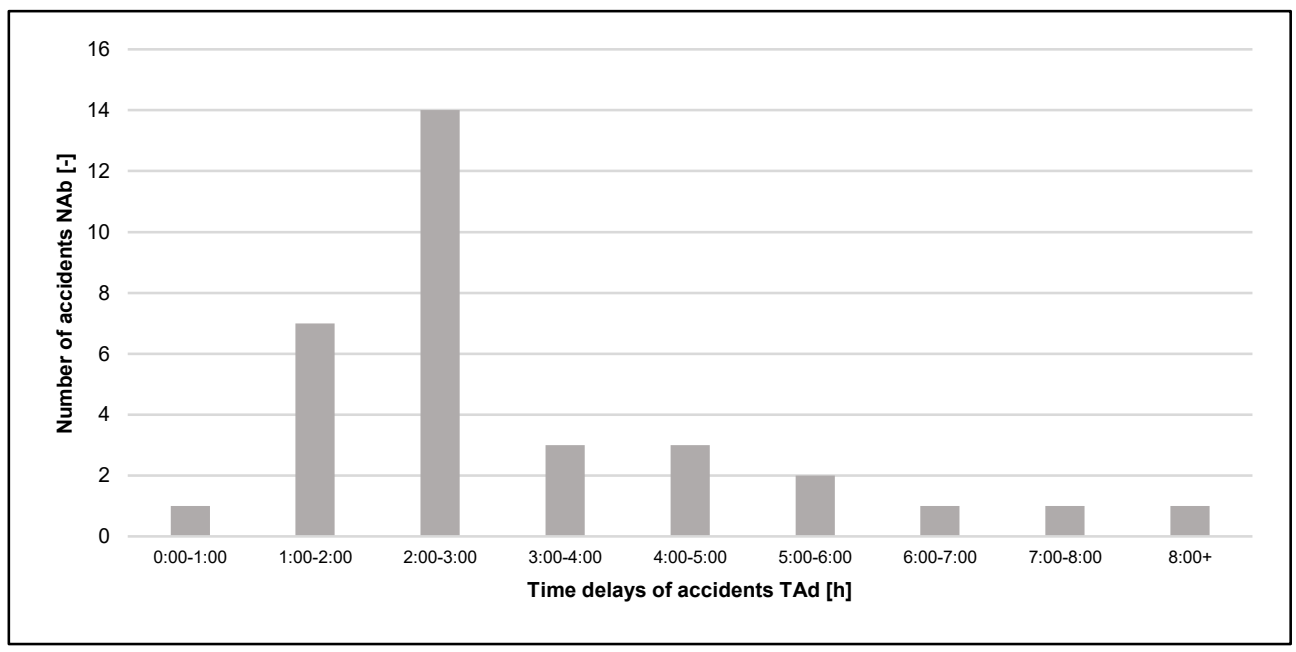

Fig. 5. Distribution of traffic disruption time following an accident on selected sections of the S12 national road in 2017 


\subsection{Removal costs}

The costs to dismantle safety barriers are incurred in the final stage of barrier service life. They will depend on the barrier material and barrier function (road, bridge). These costs are correlated with construction costs. Preliminary studies have shown that the costs of removal represent about $20 \%$ of construction costs.

\section{Conclusion}

The objective of the work was to define the structure of safety barrier costs and identify the key cost factors over the whole service life of a device. This was based on international experience with LCC and an analysis of components that make up a database created in the LifeRoSE project. A three-tier cost structure was developed as presented in 3.1 in Figure 1. The first general level takes account of recurring and non-recurring costs as can be seen from US experience [8]. The detailed split shows the costs in the successive life cycle phases just as in the United Kingdom [9] and Sweden[10]: costs of investment, maintenance, users and removal. The final level identifies the details of cost components that have an effect on total costs of safety barriers during the entire life cycle.

Not all of the factors identified in international experience could be analysed because some are not available (e.g. the cost and time to clean barrier elements). The authors used data collected under the LifeRoSE project and found that fixed costs are driven primarily by safety barrier construction costs (installation and purchase). It was established that variable costs depend mainly on the costs of repairs, road user delays and road accidents. The first category of costs (fixed) depends on barrier design costs such as the material, barrier designation, weight, containment level and working width. When defining variable costs, it is important to pay special attention to estimating the number and severity of road accidents, delays and total length of damage to barriers. They depend on road and traffic parameters and barrier type.

Further research work will be designed to develop models of delays to road users, accidents and length of damage. Once complete, the results will help to build a universal method for assessing the life cycle costs of safety barriers.

Identification and analyses of the life cycle costs factors of road safety barriers are conducted under a research project for the NCBiR (National Centre for Research and Development) and the GDDKiA (General Directorate for National Roads and Motorways): Project RID 3B "The effects of time and inuse conditions on the durability and functionality of road safety devices".

\section{References}

1. H. Karim, R. Magnusson, K. Natanaelsson, Life-Cycle Cost Analyses for Road Barriers, J. Transp. Eng. 138 pp. 830-851 (2012). doi:https://doi.org/10.1061/(ASCE)TE.19435436.0000391

2. K. Jamroz, M. Budzyński, W. Kustra, L. Michalski, S. Gaca, Tools for road infrastructure safety management - Polish experiences, in: Transp. Res. Procedia, pp. 730-739 (2014). doi:10.1016/j.trpro.2014.10.052

3. A. Tułecki, M. Szkoda, Koszt cyklu trwałośći LCC jako model decyzyjny modernizacji pojazdów szynowych, Zesz. Nauk. Inst. Pojazdów. 64 pp. 10 (2007)

4. The Polish Committee for Standardization, PN-EN 60300-3-3 Dependability management - Part 3-3: Application guide. Life cycle costing (2006)

5. I. Dziaduch, Modele szacowania kosztu cyklu życia: przegląd literatury, Logistyka. (2016)

6. W. Fabrycky, B.S. Blanchard, Life-Cycle Cost and Economic Analysis (Prentice Hall 
International Series in Industrial and Systems Engineering, New York, 1991)

7. M. Chaberek, Makro- i mikroekonomiczne aspekty wsparcia logistycznego (Wydawnictwo Uniwersytetu Gdańskiego, Gdańsk, 2002)

8. S.A. Cooner, Y.K. Rathod, D.C. Alberson, R.P. Bligh, E.R. Stephen, D. Sun, Performance Evaluation of Cable Median Barrier Systems in Texas. Report No. FHWA/TX-09/0-5609-1 (Texas Department of Transportation, 2009)

9. G.L. Williams, Whole Life Cost-Benefit Analysis for Median Safety Barriers (Transport Research Laboratory, 2007)

10. H. Karim, Improved Road Design for Future Maintenance - Analysis of Road Barrier Repair Costs. Licentiate Thesis, Royal Institute of Technology, 2008

11. H. Karim, M. Alam, R. Magnusson, Road Barrier Repair Costs and Influencing Factors, J. Transp. Eng. 137 pp. 349-359 (2011). doi:https://doi.org/10.1061/(ASCE)TE.1943-5436.0000227

12. B. Grzyl, A. Kristowski, K. Jamroz, A. Gobis, Methods of estimating the cost of traffic safety equipment's life cycle, MATEC Web Conf. 122 (2017). doi:10.1051/matecconf/20171220 2003

13. Ł. Jeliński, K. Jamroz, J. Jamroz, M. Antoniuk, Functionality of road safety devices identification and analysis of factors, MATEC Web Conf. 122 (2017). doi: $10.1051 /$ matecconf $/ 201712202005$

14. G. Bagiński, Wpływ stosowanych środków i urządzeń BRD na koszty utrzymania dróg, in: II Pomor. Forum Drog., (Gdynia, 2017)

15. M. Antoniuk, Ł. Jeliński, Badanie wpływu rodzaju otoczenia drogi na liczbę i skutki niebezpiecznych zdarzeń drogowych na przykładzie dróg krajowych województwa pomorskiego (in Polish). Master Thesis (Gdansk University of Technology, 2014)

16. D. Nycz, Modelowanie i badania numeryczne testów zderzeniowych bariery klasy N2-W4-A na łukach dróg, Wojskowa Akademia Techniczna, 2015

17. D. Hong, Y. Lee, J. Kim, W. Kim, Development of Traffic Accident Prediction Models, Proc. East. Asia Soc. Transp. Stud. 5 pp. 2046-2061 (2005)

18. B. Strzebrakowska, Simulation of the impact of dangerous road incidents on driver's loss of time on express roads, MATEC Web Conf. 122 (2017). doi:https://doi.org/10.1051/matecconf/201712202004

19. B. Strzebrakowska, Analiza strat czasu użytkowników ruchu na autostradach, wynikających z niespodziwanych zdarzeń drogowych., Gdansk University of Technology, 2016 